\title{
Analisis Error Terhadap Peramalan Data Penjualan
}

\author{
Error Analysis Toward Sales Data Forecasting
}

\author{
Alyauma Hajjah ${ }^{1}$, Yulvia Nora Marlim² \\ ${ }^{1,2}$ Teknik Informatika, Ilmu Komputer, Institut Bisnis dan Teknologi Pelita Indonesia \\ E-mail: ${ }^{1}$ alyauma.hajjah@lecturer.pelitaindonesia.ac.id, \\ 2yulvia.nora@lecturer.pelitaindonesia.ac.id
}

\begin{abstract}
Abstrak
Peramalan merupakan suatu metode yang digunakan untuk memperkirakan nilai dimasa depan dengan menggunakan nilai masa lalu. Penelitian ini membahas tentang analisis error terhadap peramalan permintaan suatu barang menggunakan metode Moving Average dan Exponential Smoothing. Pada Metode Moving Average digunakan untuk peramalan periode 3 bulan dan 5 bulan, sedangkan metode Exponential Smoothing menggunakan parameter $\alpha=0,1 ; 0,5 ; 0,7$ dan 0,9 . Analisis error bertujuan untuk membandingkan tingkat kesalahan (error) dari hasil peramalan, analisis error yang digunakan adalah Mean Absolut Deviation (MAD), Mean Squared Error (MSE), dan Mean Absolute Percentage Error (MAPE). Metode yang memiliki tingkat error terkecil adalah metode yang direkomendasikan untuk digunakan dalam proses peramalan permintaan suatu barang. Berdasarkan hasil penelitian ini metode yang memiliki tingkat kesalahan terkecil adalah metode Exponential Smoothing dengan parameter $\alpha=0,9$, yang memiliki nilai $M A D=1.214,54 ; M S E=2.758 .993$ dan $M A P E=9,17 \%$ atau dengan tingkat keakuratan peramalannya sebesar $90,83 \%$. Sehingga untuk peramalan permintaan untuk bulan berikutnya peneliti merekomendasikan menggunakan metode Exponential Smoothing dengan perameter $\alpha=0,9$.
\end{abstract}

Kata kunci: peramalan, error, Moving Average, Exponential Smoothing.

\begin{abstract}
Forecasting is a method used to estimate future value using past values. This study discuses error analysis on forecasting the demand for an item using the Moving Average and Exponential Smoothing methods. The Moving Average method is used for forecasting periods of 3 months and 5 months, while the Exponential Smoothing method uses a parameters $\alpha=0.1$; 0.5; 0.7 and 0.9. Error analysis aims to compare the forecasting results, the error analysis used is Mean Absolute Deviation (MAD), Mean Squared Error (MSE), and Mean Absolute Percentage Error (MAPE). The method that has the smallest error rate is the recommended method for use in the process of forecasting the denabd for an item. Based on the results of this study the method that has the smallest error rate is the Exponential Smoothing method with a parameter $\alpha=0.9$, which has a value of MAD =1,214.54; $M S E=2,758,993$ and MAPE = $9.17 \%$ or with a level of prediction accuracy of $90.83 \%$. So as to forecast demand for the following month the researcher recommends using the Exponential Smoothing method with a parameter $\alpha=0.9$.
\end{abstract}

Keywords: forecasting, error, Moving Average, Exponential Smoothing.

\section{PENDAHULUAN}

Perusahaan yang bergerak dalam bidang pendistribusian barang selalu menginginkan kesuksesan pada masa yang akan datang. Untuk mencapai ini perusahaan harus selalu berusaha untuk tetap dapat berkembang dalam usahanya. Pimpinan harus memiliki kemampuan dalam mengambil suatu keputusan yang tepat dalam menghadapi situasi yang akan datang yang penuh ketidakpastian, olehkarena itu perusahaan harus mampu meramalkan penjualan atau permintaan 
pelanggan akan barang yang dihasilkan. Manajer perusahaan selalu memiliki keinginan untuk bisa memprediksi berapa jumlah permintaan jangka pendek maupun jangka panjang. Olehkarena itu dibutuhkan sebuah metode untuk memprediksi jumlah permintaan atau penjualan.

CV. Sinar Abadi merupakan perusahaan yang bergerak dibidang penjualan alat listrik. Salah satu produknya adalah Lampu LED bermerk Sanyo. Perusahaan ini merupakan satusatunya distributor lampu LED bermerek Sanyo di kota Pekanbaru. Perusahaan ini dalam melakukan stok lampu tidak sesuai dengan permintaan konsumen sehingga menimbulkan penumpukan lampu yang berlebih digudang, hal ini menyebabkan biaya penyimpanan barang pun naik. Perusahaan melakukan pengorderan lampu setiap bulan seara berkala. Permintaan lampu untuk tiap bulan tidak tetap, ada kalanya permintaan banyak dan bisa juga permintaan menurun sehingga perusahaan kesulitan dalam mengatur stok lampu dan terjadinya penumpukan barang digudang sehingga perusahaan mengalami kerugian. Kerugian bisa juga disebabkan karena jumlah permintaan barang tidak sesuai dengan stok barang [1]. Dengan adanya peramasalahan tersebut dibutuhkan sebuah peramalan untuk mengatur stok barang digudang [2].

Peramalan merupakan suatu ilmu yang berguna untuk memperkirakan nilai atau kejadian masa yang akan datang. Setiap perusahaan menginginkan keuntungan maksimum sehingga dibutuhkan suatu teknik peramalan penjualan barang yang efektif sehingga tidak terjadi penumpukan barang di gudang [3]. Salah satu metode yang sering digunakan dalam peramalan adalah metode Moving Average dan metode Exponential Smoothing. Peramalan merupakan suatu teknik dalam memperkirakan nilai pada periode atau masa yang akan datang, dengan mengamati informasi dan data yang nyata dari data saat ini dan masa lampau [4].

Penelitian terdahulu tentang peramalan [5] menerapakan metode Single Exponential Smoothing untuk memprediksi penjulan suatu barang dalam satu bulan serta menganalisa tingkat keakuratan dan peramalan penjualan dengan membandingkan nilai dari $M A D, M S E$ dan MAPE yang dihasilkan. [6] membahas tentang peramalan penjualan hijab Scproject, metode yang digunakan untuk proses peramalan adalah metode Moving Average dan Exponential Smoothing. Memilih metode terbaik dengan membandingkan tingkat error yaitu MAD, MSE, dan MAPE untuk setiap metode. Sehingga diperoleh bahwa permalan denga hasil terbaik dengan menggunakan metode Moving Average dengan periode 4 bulan.

Penelitian oleh [7] meramalkan tentang permintaan pompa air dangkal Shimizu dengan mengambil data penjualan dan produksi selama 12 bulan pada periode Desember 2018 sampai November 2019 menggunakan metode Time Series dengan model Exponential Smoothing dan Moving Average. Penggunaan kedua metode itu digunakan untuk membandingkan hasil peramalan yang terbaik dengan dilihat dari nilai error yang paling kecil. Hasil peramalan menggunakan metode Exponential Smoothing dengan menggunakan parameter $\alpha=0,1$ merupakan metode yang paling akurat untuk meramalkan jumlah permintaan pompa air dangkal pada periode Desember 2019. Penelitian selanjunya adalah peramalan penjualan bakso kemasan /kiloan rumah bakso bang ipul menggunakan metode Exponential Smoothing dengan menggunakan parameter $\alpha=0,1 ; 0,2 ; 0,3 ; 0,4 ; 0,5 ; 0,6 ; 0,7 ; 0,8 ; 0,9$, dengan menghitung nilai error minimum dari $M A E$ dan $M S E$ di dapat dengan nilai 6,23 dan 58,32 [8].

Penelitian yang dilakukan oleh [9] membahas tentang peramalan jumlah kasus penyakit hipertensi, dalam proses peramalan menggunakan metode Time Series dengan model Exponential Smoothing. Data yang diuji dari bulan Juli 2015 hingga Juni 2018. Dari hasil pengujian diperoleh nilai $M A P E$ untuk kasus hipertensi pada laki-laki adalah $25,71 \%$, perempuan 19,63\%, pada usia $\leq 44$ tahun adalah $98,42 \%$ dan usia $\geq 45$ tahun adalah $13,98 \%$.

Berdasarkan penelitian terdahulu yang sudah, maka penelitian ini dilakukan pengembangan dan penyesuian dengan kasus yang ada. Penelitian ini untuk meramalkan perminataan barang berdasarkan data penjualan barang menggunakan metode Moving Average dan metode Exponential Smoothing. kemudian menguji metode mana yang paling akurat dalam proses peramalan menggunakan tiga jenis mengukuran yaitu Mean Absolute Deviation (MAD), Mean Square Error (MSE), dan Mean Absolute Percentace Error (MAPE). Dengan mengetahui 
metode peramalan yang terbaik untuk meramalkan penjualan perusahaan di periode yang akan datang, sehingga hasil peramalan ini bisa digunakan sebagai landasan perusahaan dalam mengambil keputusan dalam proses pengaturan stok barang sehingga tidak terjadi kekurangan dan kelebihan barang di Gudang.

\section{METODE PENELITIAN}

Penelitian ini adalah penelitian yang menggunakan Metode Kuantitatif yaitu metode peramalan yang mengutamakan pola data historis yang dimiliki. Metode peramalan yang digunakan adalah metode peramalan time series. Adapun jenis metode peramalan time series yang digunakan dalam penelitian ini adalah metode Moving Average dan metode Exponential Smoothing. Metode Moving Average memiliki keunggulan dalam proses melakukan perhitungan dari nilai data baru dan nilai data lama dihapus, tetapi metode ini memiliki kekurangan karena menggunakan bobot yang sama untuk semua nilai data sedangkan Metode Exponential Smoothing kelebihan dalam proses pengurangan masalah penyimpanan data. Kemudian untuk menentukan metode yang paling akurat dalam proses peramalkan jumlah penjualan barang di periode yang akan datang dilakukan pengujian nilai dari $M A D, M S E$ dan $M A P E$, yang berguna untuk mengetui tingkat kesalahan dari masing-masing metode peramalan. Metode peramalan dikatakan paling akurat jika nilai $M A D, M S E$ dan MAPE yang diperoleh paling kecil.

\subsection{Metode Moving Average}

Metode Moving Average merupakan metode peramalan sederhana dan sangat mudah untuk digunakan. Metode ini digunakan saat data tidak dipengaruhi oleh tren. Apabila terjadi tren maka peramalan ini tidak bekerja maksimal. Metode Moving Average adalah metode peralaman dari sekelompok data pengamatan serta menghitung nilai rata-rata dari data tersebut sebagai nilai ramalan untuk periode yang akan datang [10].

Peramalan menggunakan metode Moving Average melakukan proses perhitungan dari nilai data yang paling baru serta menghapus nilai data yang lama. Nilai rata-rata diperoleh dari jumlah data yang nilai rata-ratanya bergerak dari harga 1 sampai t data yang diketahui. Berikut ini adalah persamaan dari Metode Moving Average [10].

dengan,

$$
\begin{gathered}
M_{t}=F_{t+1} \\
F_{t+1}=\frac{A_{t}+A_{t-1}+A_{t-2}+\cdots+A_{t-n+1}}{n}
\end{gathered}
$$

$$
\begin{array}{ll}
M_{t} & =\text { Nilai dari Moving Average untuk periode } t \\
F_{t+1} & =\text { Nilai ramalan untuk periode } t+1 \\
A_{t} & =\text { Nilai actual untuk periode } \mathrm{t} \\
n & =\text { Jumlah data }
\end{array}
$$

\subsection{Metode Exponential Smoothing}

Metode Exponential Smoothing adalah metode peramalan rata-rata bergerak dengan sistem pembobotan yang canggih, namun masih mudah digunakan [11]. Metode Exponential Smoothing umumnya digunakan untuk meramalkan data dengan pola tidak tetap atau pola dengan perubahan besar dan bergejolak. Berikut ini adalah persamaan untuk metode Exponential Smoothing yaitu.

$$
\begin{aligned}
\qquad F_{t}=F_{t-1}+\alpha\left(A_{t-1}-F_{t-1}\right) \\
\text { dengan } F_{t} \quad=\text { peramalan pada periode } t \\
F_{t} \quad=\text { peramalan pada periode } t-1 \\
\alpha \quad=\text { nilai konstanta Smoothing }(0<\alpha<1) \\
A_{t-1}=\text { permintaan actual periode } t-1
\end{aligned}
$$

Metode Exponential Smoothing memiliki kelebihan yaitu banyak mengurangi masalah proses penyimpanan data, sehingga tidak semua data historis di simpan atau hanya Sebagian 
data yang perlu disimpan yaitu data pengamatan terakhir, hasil data peramalan terakhir dan nilai suatu parameter atau konstanta.

\subsection{Analisa Error}

Dalam proses peramalan hasil peramalan yang diperoleh setiap metode umumnya berbeda karena hasil peramalan mengandung unsur derajat ketidakpastian. Sehingga untuk mengetahui data peramalan yang lebih akurat diperlukan beberapa perhitungan untuk mengukur kesesuaian antara data actual dengan data peramalan. Ada bebera perhitungan yang sering digunakan dalam menghitung kesalahan peramalan total yaitu Mean Absolute Deviasi (MAD), Mean Squared Error (MSE), dan Mean Absolute Percentage Error (MAPE).

\subsubsection{Mean Absolute Deviation (MAD)}

$M A D$ adalah rata-rata dari nilai mutlak dari seluruh kesalahan dalam proses hasil peramalan, tanda mutlak berguna untuk menghindari terjadinya nilai kesalahan negatif. Semakin kecil nilai $M A D$ yang diperoleh maka semakin bagus hasil peramalan, Nilai $M A D$ dapat dihitung dengan menggunakan persamaan berikut ini [12].

dengan,

$$
M A D=\frac{\sum_{t=1}^{n}\left|A_{t}-F_{t}\right|}{n}
$$

$A_{t} \quad=$ Nilai actual pada periode $t$

$F_{t} \quad=$ Nilai peramalan pada periode $t$

$n \quad=$ Jumlah data

\subsubsection{Mean Absolute Deviation (MSE)}

Teknik perhitungan $M S E$ dengan menghitung jumlah selisih dari data peramalan dengan data actual [13]. Semakin kecil nilai MSE maka hasil peramalan semakin bagus. Nilai $M S E$ dapat dihitung dengan menggunakan persamaan berikut ini [14].

$$
M S E=\frac{\sum_{t=1}^{n}\left(A_{t}-F_{t}\right)^{2}}{n}
$$

\subsubsection{Mean Absolute Percentage Error (MAPE)}

MAPE digunakan untuk mengetahui tingkat akurasi hasil peramalan. MAPE adalah menghitung nilai kesalahan mutlak pada setiap periode dibagi dengan nilai aktual untuk periode itu, kemudian menghitung rata-rata persentasi dari nilai mutlak tersebut. Nilai MAPE dapat dicari dengan menggunakan persamaan sebagai berikut [15]:

$$
M A P E=\left(\sum_{t=1}^{n} \frac{\left|A_{t}-F_{t}\right|}{A_{t}}\right)\left(\frac{100 \%}{n}\right)(5)
$$

Hasil peramalan dikatakan baik jika nilai $M A P E$ yang diperoleh semakin kecil. Adapun kriteria dari nilai $M A P E$ adalah sebagai berikut [16].

Tabel 1. Kriteria Nilai MAPE

\begin{tabular}{|c|l|}
\multicolumn{2}{|c|}{ Tabel 1. Kriteria Nilai MAPE } \\
\hline Nilai $M A P E$ & Kriteria \\
\hline$x<10 \%$ & Kemampuan peramalan sangat baik \\
\hline $10 \% \leq x<20 \%$ & Kemampuan peramalan baik \\
\hline $20 \% \leq x<50 \%$ & Kemampuan peramalan cukup baik \\
\hline$x \geq 50 \%$ & Kemampuan peramalan buruk \\
\hline
\end{tabular}

Tabel 1 menunjukkan bahwa kriteria dari nilai $M A P E$ ada 4 bagian yaitu kemampuan peramalan sangat bagus (akurat), kemampuan peramalan baik, kemampuan peramalan cukup baik dan kemampuan peramalan buruk (tidak akurat). 


\section{HASIL DAN PEMBAHASAN}

Dalam melakukan proses peramalan menggunakan data masa lalu yaitu data permintaan barang pada tahun 2019, data ini digunakan untuk melakukan peralaman pada periode selanjutnya menggunakan metode Moving Average dan metode Exponential Smoothing.

\subsection{Peramalan dengan Metode Moving Average}

Proses peramalan permintaan barang menggunakan metode Moving Average dengan periode 3 bulan, maka diperoleh hasil sebagai berikut

Tabel 2. Hasil Peramalan Menggunakan Metode Moving Average 3 Bulan

\begin{tabular}{|c|c|c|}
\hline Bulan & Aktual & Peramalan \\
\hline Januari & 12512 & \\
\hline Februari & 11203 & \\
\hline Maret & 12032 & 11915,67 \\
\hline April & 11932 & 11722,33 \\
\hline Mei & 10265 & 11409,67 \\
\hline Juni & 10321 & 10839,33 \\
\hline Juli & 9975 & 10187 \\
\hline Agustus & 9894 & 10063,33 \\
\hline September & 12456 & 10775 \\
\hline Oktober & 13548 & 11966 \\
\hline November & 17325 & 14443 \\
\hline Desember & 15675 & \\
\hline
\end{tabular}

Tabel 2 menunjukkan hasil peramalan permintaan barang menggunakan metode Moving Average 3 bulan, hasil peramalan permintaan barang untuk bulan April sebesar 11722,33 sedangkan nilai aktual permintaan barang sebesar 11932, sedangkan hasil peramalan permintaan barang periode berikutnya yaitu Januari 2020 sebesar 15516.

Tabel 3. Hasil Peramalan Menggunakan Metode Moving Average 5 Bulan

\begin{tabular}{|c|c|c|}
\hline Bulan & Aktual & Peramalan \\
\hline Januari & 12512 & \\
\hline Februari & 11203 & \\
\hline Maret & 12032 & \\
\hline April & 11932 & \\
\hline Mei & 10265 & 11588,8 \\
\hline Juni & 10321 & 11150,6 \\
\hline Juli & 9975 & 10905 \\
\hline Agustus & 9894 & 10477,4 \\
\hline September & 12456 & 10582,2 \\
\hline Oktober & 13548 & 11238,8 \\
\hline November & 17325 & 12639,6 \\
\hline Desember & 15675 & \\
\hline
\end{tabular}

Tabel 3. menunjukkan hasil peramalan permintaan barang menggunakan metode Moving Average 5 bulan, hasil peramalan permintaan barang untuk bulan Juni sebesar 11588,8 sedangkan nilai aktual permintaan barang sebesar 10321, sedangkan hasil peramalan permintaan barang periode Januari 2020 yaitu sebesar 13779,6.

\subsection{Peramalan dengan Metode Exponential Smoothing}

Proses peramalan permintaan barang menggunakan metode Exponential Smoothing dengan $\alpha=0,1$, maka diperoleh hasil sebagai berikut

Tabel 4. Hasil Peramalan Menggunakan Metode Exponential Smoothing $\alpha=0,1$

\begin{tabular}{|c|c|c|}
\hline Bulan & Aktual & Peramalan \\
\hline Januari & 12512 & \\
\hline
\end{tabular}


Techno.COM, Vol. 20, No. 1, Februari 2021: 1-9

\begin{tabular}{|c|c|c|}
\hline Februari & 11203 & 12512 \\
\hline Maret & 12032 & 12381,1 \\
\hline April & 11932 & 12346,19 \\
\hline Mei & 10265 & 12304,77 \\
\hline Juni & 10321 & 12100,79 \\
\hline Juli & 9975 & 11922,81 \\
\hline Agustus & 9894 & 11728,03 \\
\hline September & 12456 & 11544,63 \\
\hline Oktober & 13548 & 11635,77 \\
\hline November & 17325 & 11826,99 \\
\hline Desember & 15675 & 12376,79 \\
\hline
\end{tabular}

Tabel 4. menunjukkan hasil peramalan permintaan barang menggunakan metode Exponential Smoothing dengan parameter $\alpha=0,1$, hasil peramalan permintaan barang untuk bulan Februari sebesar 12512 sedangkan nilai aktual permintaan barang sebesar 11203, hasil peramalan permintaan barang untuk bulan Maret sebesar 11857,5 sedangkan nilai aktual permintaan barang sebesar 12032, sedangkan hasil peramalan permintaan barang periode Januari 2020 yaitu sebesar 12.706,61

Tabel 5. Hasil Peramalan Menggunakan Metode Exponential Smoothing $\alpha=0,5$

\begin{tabular}{|c|c|c|}
\hline Bulan & Aktual & Peramalan \\
\hline Januari & 12512 & \\
\hline Februari & 11203 & 12512 \\
\hline Maret & 12032 & 11857,5 \\
\hline April & 11932 & 11944,75 \\
\hline Mei & 10265 & 11938,38 \\
\hline Juni & 10321 & 11101,69 \\
\hline Juli & 9975 & 10711,34 \\
\hline Agustus & 9894 & 10343,17 \\
\hline September & 12456 & 10118,59 \\
\hline Oktober & 13548 & 11287,29 \\
\hline November & 17325 & 12417,65 \\
\hline Desember & 15675 & 14871,32 \\
\hline
\end{tabular}

Tabel 5. menunjukkan hasil peramalan permintaan barang menggunakan metode Exponential Smoothing dengan parameter $\alpha=0,5$, hasil peramalan permintaan barang untuk bulan Maret sebesar 11857,5 sedangkan nilai aktual permintaan barang sebesar 12032, hasil peramalan permintaan barang untuk bulan April sebesar 11944,75 sedangkan nilai aktual permintaan barang sebesar 11932, sedangkan hasil peramalan permintaan barang periode Januari 2020 yaitu sebesar 15273,16.

Tabel 6. Hasil Peramalan Menggunakan Metode Exponential Smoothing $\alpha=0,7$

\begin{tabular}{|c|c|c|}
\hline Bulan & Aktual & Peramalan \\
\hline Januari & 12512 & \\
\hline Februari & 11203 & 12512 \\
\hline Maret & 12032 & 11595,7 \\
\hline April & 11932 & 11901,11 \\
\hline Mei & 10265 & 11922,73 \\
\hline Juni & 10321 & 10762,32 \\
\hline Juli & 9975 & 10453,4 \\
\hline Agustus & 9894 & 10118,52 \\
\hline September & 12456 & 9961,35 \\
\hline Oktober & 13548 & 11707,61 \\
\hline November & 17325 & 12995,88 \\
\hline Desember & 15675 & 16026,26 \\
\hline
\end{tabular}


Tabel 6. menunjukkan hasil peramalan permintaan barang menggunakan metode Exponential Smoothing dengan parameter $\alpha=0,7$, hasil peramalan permintaan barang untuk bulan Maret sebesar 11595,7 sedangkan nilai aktual permintaan barang sebesar 12032, hasil peramalan permintaan barang untuk bulan April sebesar 11901,11 sedangkan nilai aktual permintaan barang sebesar 11932, sedangkan hasil peramalan permintaan barang periode Januari 2020 yaitu sebesar 15780,38.

Tabel 7. Hasil Peramalan Menggunakan Metode Exponential Smoothing $\alpha=0,9$

\begin{tabular}{|c|c|c|}
\hline Bulan & Aktual & Peramalan \\
\hline Januari & 12512 & 12512 \\
\hline Februari & 11203 & 11333,9 \\
\hline Maret & 12032 & 11962,19 \\
\hline April & 11932 & 11935,02 \\
\hline Mei & 10265 & 10432,0 \\
\hline Juni & 10321 & 10332,1 \\
\hline Juli & 9975 & 10010,71 \\
\hline Agustus & 9894 & 9905,67 \\
\hline September & 12456 & 12200,97 \\
\hline Oktober & 13548 & 13413,3 \\
\hline November & 17325 & 16933,83 \\
\hline Desember & 15675 & \\
\hline
\end{tabular}

Tabel 7. menunjukkan hasil peramalan permintaan barang menggunakan metode Exponential Smoothing dengan parameter $\alpha=0,9$, hasil peramalan permintaan barang untuk bulan Maret sebesar 11333,9 sedangkan nilai aktual permintaan barang sebesar 12032, hasil peramalan permintaan barang untuk bulan April sebesar 11962,19 sedangkan nilai aktual permintaan barang sebesar 11932, sedangkan hasil peramalan permintaan barang periode Januari 2020 yaitu sebesar 15800,88.

\subsection{Analisa Metode Peramalan Terpilih}

Setelah proses peramalan dilakukan menggunakan metode Moving Average dan Exponential Smoothing, maka tahapan selanjutnya adalah menentukan metode mana yang lebih efektif yaitu dengan menggunakan analisa kesalahan peramalan. Perhitungan kesalahan peramalan dilakukan dengan menggunakan Mean Absolute Deviasi (MAD), Mean Squared Error (MSE), dan Mean Absolute Percentage Error (MAPE). Berikut ini rekapitulasi perhitungan kesalahan peramalan.

Tabel 8. Rekapitulasi Analisa Kesalahan Peramalan

Tabel 8. Rekapitulasi Analisa Kesalahan Peramalan
\begin{tabular}{|c|c|c|c|c|}
\hline Metode & & $M A D$ & $M S E$ & MAPE \\
\hline Moving Average & 3 Bulan & $1.719,60$ & 5.310 .366 & $12,77 \%$ \\
\hline & 5 Bulan & $2.502,91$ & 8.996 .826 & $18,08 \%$ \\
\hline Exponential Smoothing & $\alpha=0,1$ & $1.935,77$ & 5.644 .221 & $15,22 \%$ \\
\hline & $\alpha=0,5$ & $1.404,09$ & 3.745 .457 & $10,72 \%$ \\
\hline & $\alpha=0,7$ & $1.235,78$ & 3.054 .715 & $9,45 \%$ \\
\hline & $\alpha=0,9$ & $1.214,54$ & 2.758 .993 & $9,17 \%$ \\
\hline
\end{tabular}

Tabel 8. merupakan perbandingan kesalahan peramalan permintaan barang untuk masingmasing metode. Berdasarkan tabel perbandingan kesalahan peramal diatas diperoleh bahwa peramalan menggunakan metode Moving Average periode 3 bulan memiliki nilai $M A D=$ $1.719,60 ; M S E=5.310 .366$ dan $M A P E=12,77 \%$ dan hasil peramalan menggunakan metode Moving Average periode 3 bulan adalah bagus karena nilai MAPE berada pada interval nilai antara $10 \%$ dan $20 \%$, sedangkan peramalan menggunakan metode Moving Average periode 5 bulan memperoleh nilai $M A D=2.502,91 ; M S E=8.996 .826$ dan $M A P E=18,08 \%$ dan hasil peramalan menggunakan metode Moving Average periode 5 bulan adalah bagus karena nilai MAPE berada pada interval nilai antara $10 \%$ dan $20 \%$. Peramalan menggunakan metode 
Exponential Smoothing dengan nilai $\alpha=0,1$ memperoleh nilai $M A D=1.935,77 ; M S E=$ 5.644.221; dan $M A P E=15,22 \%$ dan hasil peramalan menggunakan metode Exponential Smoothing dengan nilai $\alpha=0,1$ adalah bagus karena nilai MAPE berada pada interval nilai antara $10 \%$ dan 20\%. Untuk $\alpha=0,5$ memperoleh nilai $M A D=1.404,09 ; M S E=3.745 .457$ dan MAPE sebesar $10,72 \%$, dan hasil peramalannya adalah sangat bagus nilai MAPE kurang dari 10\%. Peramalan menggunakan metode Exponential Smoothing dengan $\alpha=0,7$ memperoleh nilai $M A D=1.235,78 ; M S E=3.054 .715$ dan $M A P E$ sebesar $9,45 \%$ dan hasil peramalannya adalah sangat bagus nilai $M A P E$ kurang dari $10 \%$, sedangkan untuk $\alpha=0,9$ memperoleh nilai $M A D=1.214,54 ; M S E=2.758 .993$ dan $M A P E=9,17 \%$ dan hasil peramalannya adalah sangat bagus nilai MAPE kurang dari $10 \%$.

\subsection{Analisa Penentuan Peramalan Jumlah Permintaan Lampu LED}

Setelah melakukan proses peramalan, maka metode peramalan yang lebih efisien adalah metode peramalan Exponential smoothing dengan $\boldsymbol{\alpha}=\mathbf{0 , 9}$ karena menghasilkan nilai error yang lebih kecil jika dibandingkan dengan metode lainnya dengan tingkat keakuratan peramalannya sebesar $90,83 \%$. Peramalan permintaan terhadap lampu merk Sanyo untuk bulan berikutnya adalah sebanyak 15800,88 atau 15801 artinya pihak perusahaan harus menyediakan stok lampu sebanyak 15801 untuk memenuhi perminataan lampu bulan berikutnya agar perusahaan tidak mengalami kekurangan atau kelebihan persediaan lampu sehingga perusahaan bisa memperoleh keuntungan sesuai yang diinginkan.

\section{KESIMPULAN DAN SARAN}

Metode Moving Average dan Exponential Smoothing adalah metode yang digunakan untuk melakukan suatu peramalan. Berdasarkan hasil peramalan menggunakan metode Moving Average dan Exponential Smoothing serta analisa error untuk setiap metode, maka dapat dilihat bahwa nilai $M A D, M S E$ dan MAPE terkecil berada pada metode Exponential Smoothing dengan $\alpha=0,9$, memperoleh nilai $M A D=1.214,54 ; M S E=2.758 .993$ dan $M A P E=9,17 \%$. Sehingga dapat disimpulkan bahwa metode Exponential Smoothing dengan $\alpha=0,9$ merupakan metode yang paling efektif digunakan untuk meramalkan jumlah permintaan lampu LED untuk bulan berikutnya. Berdasarkan Analisa penentuan peramalan jumlah perminataan lampu LED untuk bulan berikutnya adalah sebanyak 15800,88 atau 15801. Sehingga perusahaan harus menyediakan stok lampu sesuai jumlah permintaan lampu.

Saran untuk penelitian berikutnya adalah melakukan proses peramalan menggunakan beberapa metode yang lain serta membandingkan hasil peramalan yang lebih efisien dilihat dari error yang diperoleh untuk setiap metode.

\section{DAFTAR PUSTAKA}

[1] G. Costaner Loneli , Syafitri Wenny, 2019, Optimasi Jumlah Produksi Usaha Dagang Roti Prima Sari Menggunakan Metode Logika Fuzzy, SISTEMASI, vol. 8, no. September, pp. 424-435.

[2] A. H. Hutasuhut, W. Anggraeni, and R. Tyasnurita, 2014, Pembuatan Aplikasi Pendukung Keputusan untuk Peramalan Persediaan Bahan Baku Produksi Plastik Blowing dan Inject Menggunakan Metode ARIMA (Autoregressive Integrated Moving Average) di CV. Asia, J. Tek. Pomits, vol. 3, no. 2, pp. 70-171.

[3] A. Nurlifa and S. Kusumadewi, 2017, Sistem Peramalan Jumlah Penjualan Menggunakan Metode Moving Average Pada Rumah Jilbab Zaky, INOVTEK Polbeng Seri Inform., vol. 2, no. 1, p. 18, doi: 10.35314/isi.v2i1.112.

[4] N. D. Nachrowi and H. Usman, 2004, Teknik Pengambilan Keputusan: dilengkapi teknik analisis dan pengolahan data menggunakan paket program LINDO dan SPSS. Jakarta: Gramedia Widiasarana Indonesia. 
[5] K. M. S and S. P. W, 2015, ANALISA DAN PENERAPAN METODE SINGLE EXPONENTIAL SMOOTHING UNTUK PREDIKSI PENJUALAN PADA PERIODE TERTENTU (Studi Kasus : PT. Media Cemara Kreasi), in Prosiding SNATIF, vol. 2, pp. 259-266.

[6] K. Khamaludin, 2019, Peramalan Penjualan Hijab Sxproject Menggunakan Metode Moving Average Dan Exponential Smoothing, Unistek, vol. 6, no. 2, pp. 13-16, doi: 10.33592/unistek.v6i2.249.

[7] Pajri Al Zukri, 2020, Syndi Nurina Widyaningrum; Qurrotul Aini, Forecasting Permintaan Pompa Air Dangkal Shimizu Menggunakan Metode Time Series, SISTEMASI, vol. 9, no. 2, pp. 226-234.

[8] H. Ihsan, R. Syam, and F. Ahmad, 2018, Peramalan Penjualan dengan Metode Exponential Smoothing (Studi Kasus : Penjualan Bakso Kemasaan/Kiloan Rumah Bakso Bang Ipul), J. Math. Comput. Stat., vol. 1, no. 1, pp. 1-7.

[9] N. G. Putri, Y. T. Herawati, and A. Ramani, 2019, Peramalan Jumlah Kasus Penyakit Hipertensi Di Kabupaten Jember Dengan Metode Time Series, J. Heal. Sci. Prev., vol. 3, no. 1, pp. 39-46, doi: 10.29080/jhsp.v3i1.161.

[10] S. A. Abdul Karim and S. A. Alwi, 2013, Electricity load forecasting in UTP using moving averages and exponential smoothing techniques, Appl. Math. Sci., vol. 7, no. 7780, pp. 4003-4014, doi: 10.12988/ams.2013.33149.

[11] B. Putro, M. T. Furqon, and S. H. Wijoyo, 2018, Prediksi Jumlah Kebutuhan Pemakaian Air Menggunakan Metode Exponential Smoothing ( Studi Kasus : PDAM Kota Malang ), J. Pengemb. Teknol. Inf. dan Ilmu Komput. Univ. Brawijaya, vol. 2, no. 11, pp. 46794686.

[12] R. Rachman, 2018, Penerapan Metode Moving Average Dan Exponential Smoothing Pada Peramalan Produksi Industri Garment, J. Inform., vol. 5, no. 1, pp. 211-220, doi: 10.31311/ji.v5i2.3309.

[13] D. M. Efendi and F. Ardhy, 2018, Penerapan Data Mining Untuk Peramalan Penjualan Obat dengan Menggunakan Single Exponential Smoothing di Apotek Hamzah Farma, Semin. Nas. Teknol. dan Bisnis, pp. 198-203.

[14] R. Rahmadayanti, B. Susilo, and D. Puspitaningrum, 2015, Perbandingan Keakuratan Metode Autoregressive Integrated Moving Average (Arima) dan Exponential Smoothing pada Peramalan Penjualan Semen di PT Sinar Abadi, J. Rekursif, vol. 3, no. 1, pp. 2336.

[15] I. Sungkawa and R. T. Megasari, 2011, Penerapan Ukuran Ketepatan Nilai Ramalan Data Deret Waktu Dalam Seleksi MOdel Peramalan Volume Penjualan PT Satriamandiri Citramulia, ComTech, vol. 2, no. 2, pp. 636-645.

[16] P. C. Chang, Y. W. Wang, and C. H. Liu, 2007, The development of a weighted evolving fuzzy neural network for PCB sales forecasting, Expert Syst. Appl., vol. 32, no. 1, pp. 86-96, doi: 10.1016/j.eswa.2005.11.021. 